\title{
Improved energy efficiency and optimization of microclimate in buildings
}

\author{
Vesna Trifunovič Dragišić ${ }^{a}$, \\ College of Applied Studies in Civil Engineering and Geodesy, University of Belgrade, Hajduk Stankova 2, 11000 \\ Belgrade, Serbia
}

\begin{abstract}
Nowadays it is possible to reduce energy consumption without losing comfort as a result of using efficient energy saving technologies and advanced environment control methods for buildings. One of the measures to improve energy performance of buildings can be installation of decentralized air intake and exhaust mechanical ventilation systems with plate heat exchangers in apartments making it possible to «return» up to $85 \%$ of thermal energy. The article deals with the decentralized system controlled ventilation with heat recovery and alternative solutions heating supply air in residential buildings.
\end{abstract}

\section{Introduction}

Improved energy efficiency of buildings is one of the most urgent problems of construction science nowadays. Lower energy consumption and energy saving technologies make it possible to comply with the standards of sustainable development of the society and provide comfort to every household. Energy consumption of the municipal sector accounts for about $40 \%$ of the total amount. Reduced energy consumption and improving the quality of the microclimate inside the buildings are the main goals of energy-efficient renovation of old buildings [1-5]. Besides, energy efficient upgrading of old buildings will improve the indoor climate, reduce the cost of electricity and heat, decrease carbon dioxide emissions, increase present value of the building and improve its condition and durability. Schematic diagrams of the ventilation systems of historic buildings are shown in Figure 1 [3-5]
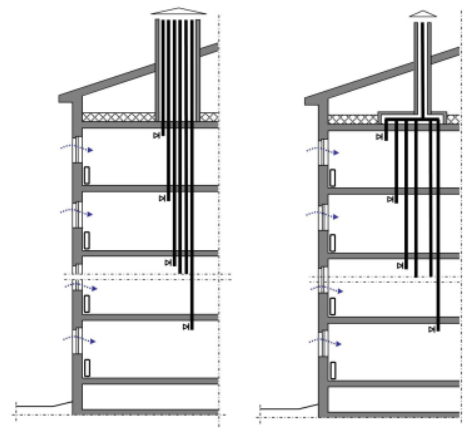

Figure 1. Schematic diagrams of the ventilation systems of historic buildings.

\footnotetext{
${ }^{\mathrm{a}}$ Corresponding author : vesna.tg@bk.ru
} 
A set of measures should be taken to achieve reduction of heat energy needed for residential buildings. These could be the following measures: thermal insulation of the building's envelope, recovery of heat from ventilation emissions wastewater disposal, heating systems optimization. Heat energy can be saved to a significant extent due to heat recovery in building ventilation system . The «Passive house» concept has appeared to be the most valuable one with respect to energy efficiency. The rate of $15 \mathrm{~kW} /\left(\mathrm{m}^{2}\right.$ per year) is the typical one in matter of energy consumption needed to heat a «passive house» under weather conditions of Central Europe. In Stockholm it can reach $20 \mathrm{~kW} /\left(\mathrm{m}^{2}\right.$ per year), and in Rome it can't be over $10 \mathrm{~kW} /\left(\mathrm{m}^{2}\right.$ per year) [5]. The concept is based on the statement to reduce heating costs to zero and achieve constant comfortable temperatures owing to efficient thermal insulation and impermeability of a building's envelope, any home heat recovery and passive solar heating (Figure 2).

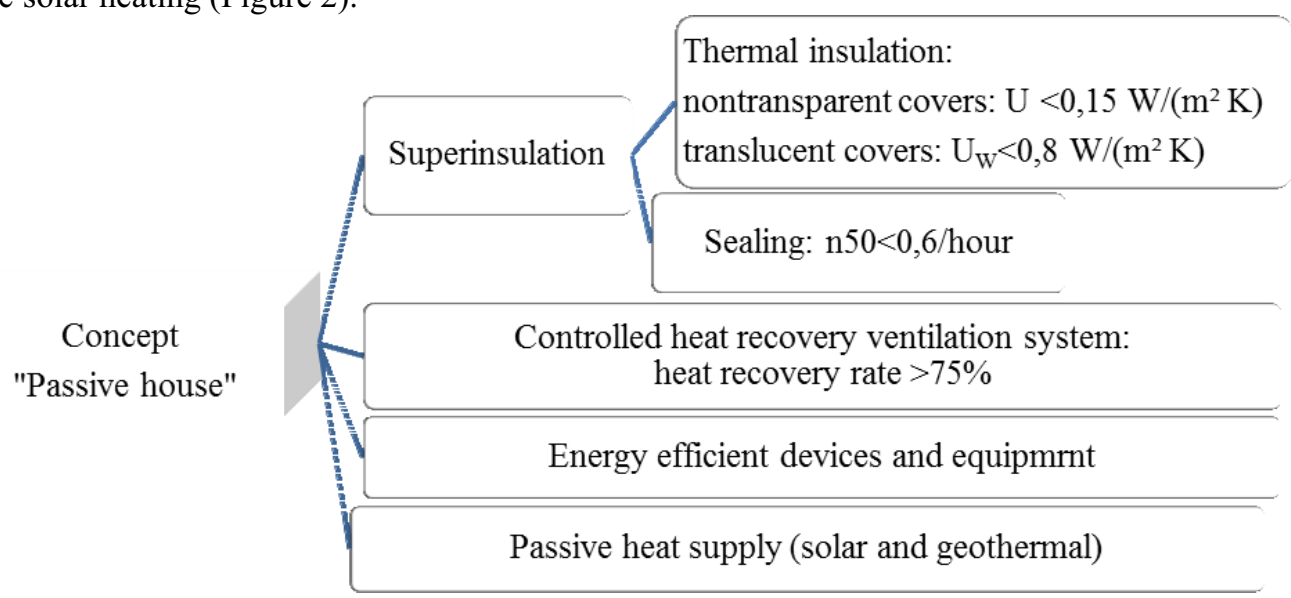

Figure 2. Basic components of the «Passive house» concept.

\section{Decentralized ventilation system in residential buildings and apartments}

One of the measures to improve energy performance of buildings can be installation of decentralized air intake and exhaust mechanical ventilation systems with plate heat exchangers in apartments making it possible to «return» up to $85 \%$ of thermal energy [7, 8]. In this case separate individual single-block intake and exhaust ventilation systems with cross-flow plate-based heat exchangers are installed in every apartment (Figure 3, 4). An air ductwork is arranged throughout every apartment. Air intake into apartments is supposed to be arranged through air diffusers, and air recovery is supposed to be arranged in kitchens, toilets and bathrooms. Outer air is heated in a heat exchanger by the air recovered from an apartment.
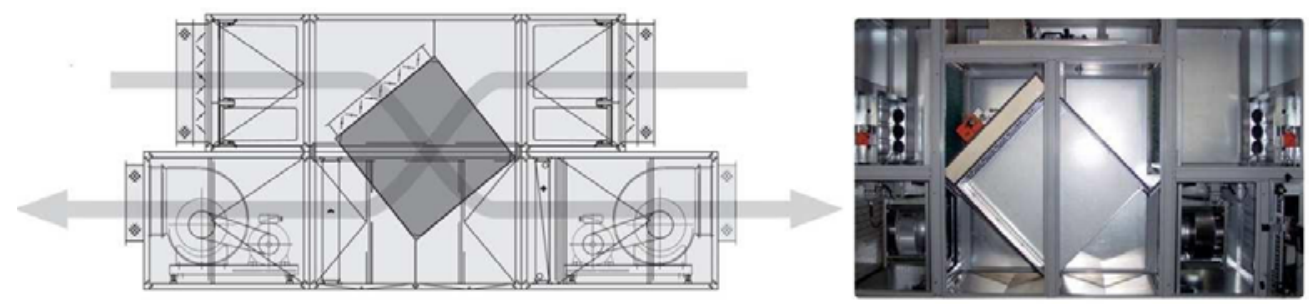

Figure 3. Plate heat exchanger designed to recover heat from air in ventilation systems and general view of a heat exchanger [6] 


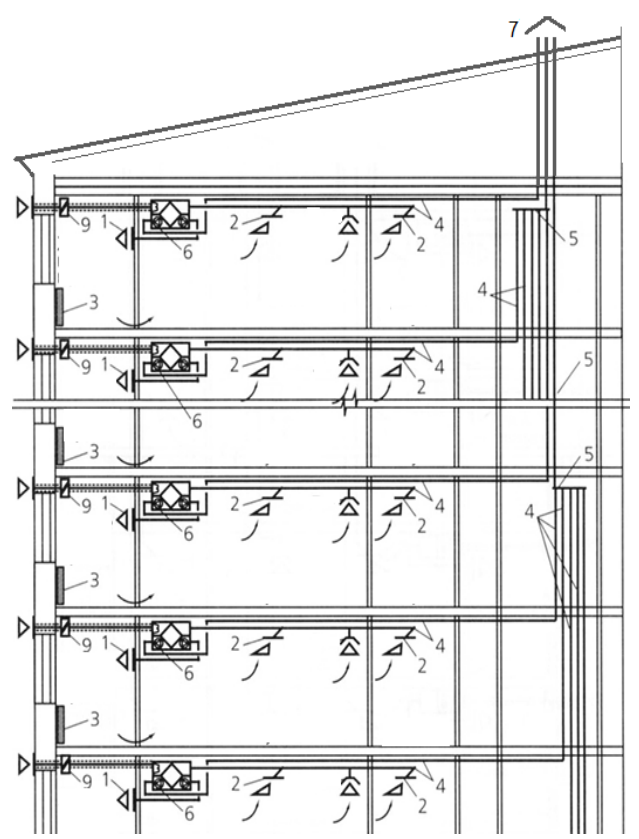

Figure 4. Scheme decentralized mechanical supply and exhaust ventilation systems with heat recovery boiler plate type [4].

1 - air intake device; 2 - exhaust device; 3 - heating device; 4 - satellite-duct; 5 - assembly exhaust duct; 6 heat exchangers (individual); 7- exhaust shaft

Fans have a possibility of 9-stage digital regulation. Residents may change air exchange levels from 0 to 9 (the value ' 0 ' implies that the system is switched off; the values 1, 2, 3 are optimal for all the types of apartments and ensure the standard level of air exchange depending on the area of apartments, the values above 3 can level air exchange up but increase the level of noise).

It is necessary to meet all the regulatory requirements for air exchange before to put energy efficient building into operation. To achieve this aim the following intake and exhaust air consumption rates have been regulated: $110 \mathrm{~m} 3 / \mathrm{h}$ is for $1-2$ room apartments, $130 \mathrm{~m} 3 / \mathrm{h}$ is for 3 - room apartments and $180 \mathrm{~m} 3 / \mathrm{h}$ is for 4 - room apartments. The balance of air consumption in intake and exhaust channels has been regulated with due account for standard exhaust air volumes in kitchens and toilets.

Dispatching systems ensure that information on the parameters of controlled air exchange modes in every apartment is received. The figure 5 shows general automated survey data on system performance in apartments in reference to actual operation quality of electric regulators meant for setting appropriate parameters by residents.

The major parameter in respect to thermal energy balance available for residents is an air exchange level. It can have impact on both the value of heat losses in the building and thermal loads between separate apartments of the building. A controlled air exchange system makes it possible to save energy due to management of ventilation at different times of the day. Air exchange level can be limited up to $50 \%$ of the standard rate for those residents who work over 70 hours a week and are outside the building (at work, in a shop, or absent for a walk) [9-13]. 


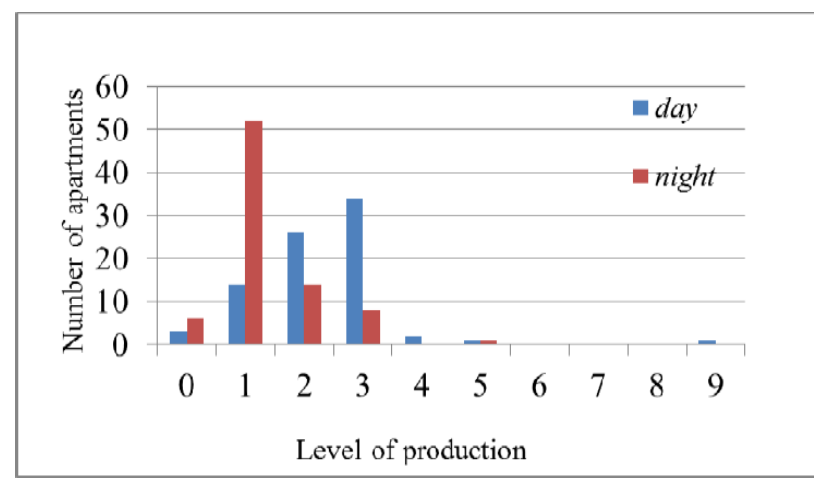

Figure 5. Air exchange level set by residents during daytime and nighttime.

The notion of comfort is subjective, often we take cold for freshness and superheated air for stuffiness. In addition, as a rule, family oriented to those to whom "cold". Mechanical ventilation system with individual control may lead to a lack of ventilation in the premises relatively normalized values. Also, for many residents an opportunity to open and close windows is a necessary component of personal comfort.

The tightness is one of the main principles energy efficiency design and construction.

In our time, "in the pursuit of energy efficiency" designed and advertised times sealed windows, do not let the air, and thus turned the main advantage of windows - ensure supply of fresh air - in a threatening health disadvantage.

Requirements of air permeability for windows in Russian regulations about air permeability changed in the following way [14]:

- $1971-18 \mathrm{~kg} /\left(\mathrm{m}^{2} \bullet \mathrm{h}\right)$;

- $1979-10 \mathrm{~kg} /\left(\mathrm{m}^{2} \bullet \mathrm{h}\right)$;

- $1998-5 \mathrm{~kg} /\left(\mathrm{m}^{2} \bullet \mathrm{h}\right)$.

The natural ventilation system of multi-storey buildings is still traditionally based on air infiltration through cracks and gaps of windows. Therefore we can conclude that imposing tougher requirements of air permeability for windows has been the first step to draught-proofing, which has led to worsening microclimate with inappropriate air interchange.

In older buildings energy efficiency reconstruction is usually started by occupants who replace their old windows, providing natural ventilation, with new tightness windows. Thereby air interchange reduces, microclimate worsens and damp rises.

It is essential to switch from energy saving at all cost to microclimate improvement. The priority target of the contemporary construction is to form the appropriate climate in living spaces.

The use of solar energy for power supply of residential buildings is a must-have for the "green design". Solar energy has been used successfully in the reconstruction and restoration of historic buildings [15 - 19].

Reception heating the incoming air in the glazed space of the building facade without the tightness of the building envelope is implemented in a number of projects (Figure 6,7,8)
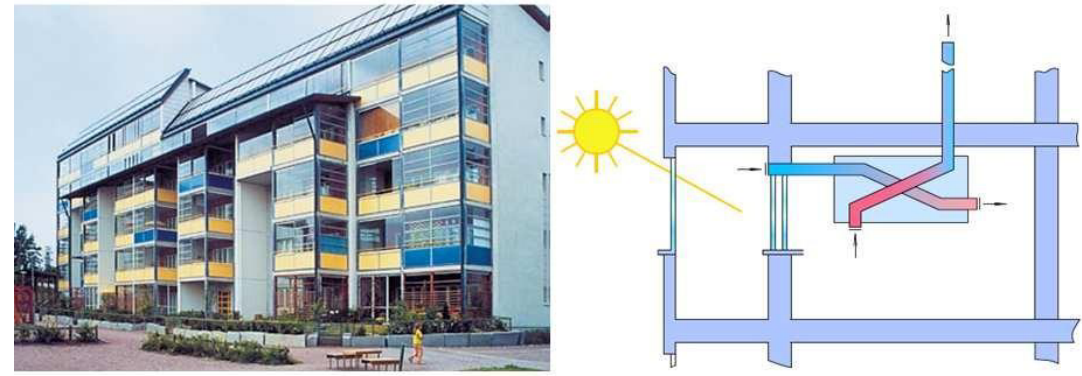

Figure 6. "Ecological housing" area Viikki, Helsinki (Finland). 

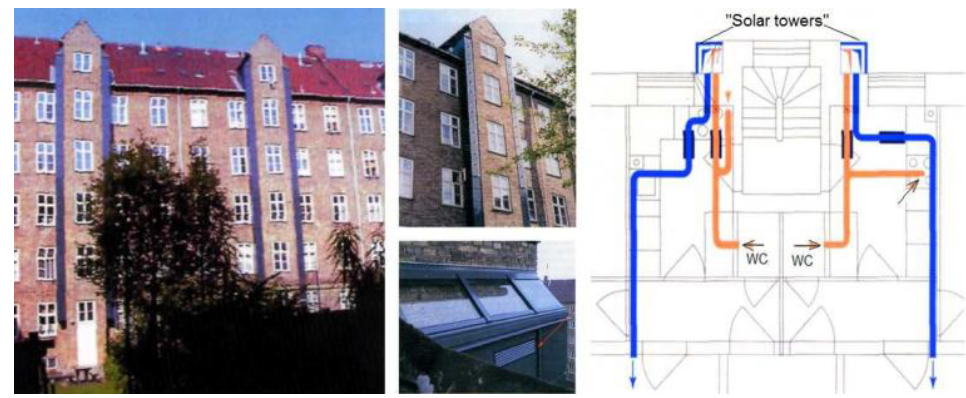

Figure 7. Reconstruction of a residential building, Frederiksberg (Denmark) [20].
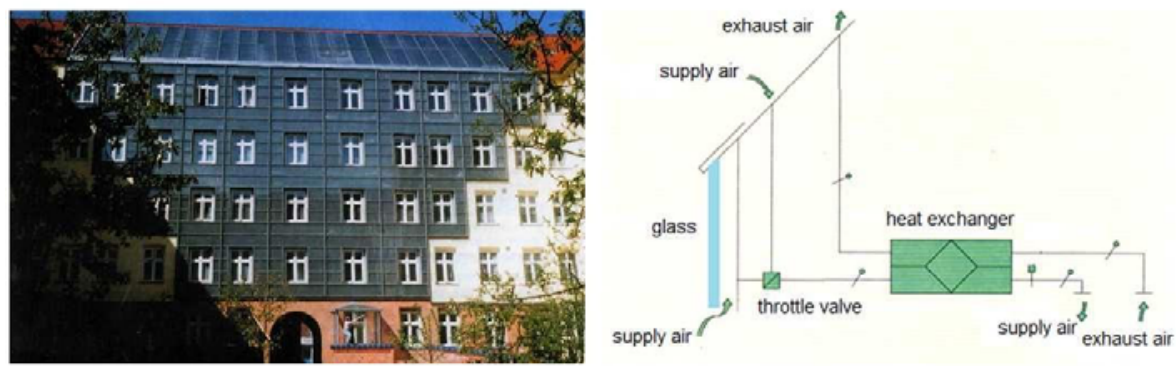

Figure 8. Reconstruction of a residential building, Østerbro, Copenhagen (Denmark) [20].

Commerzbank famous building is an example of energy-efficient construction with natural and controlled ventilation. Effective management of heat flow in a double glass façade provides natural air conditioning of the building and significant energy savings (Fig. 9)
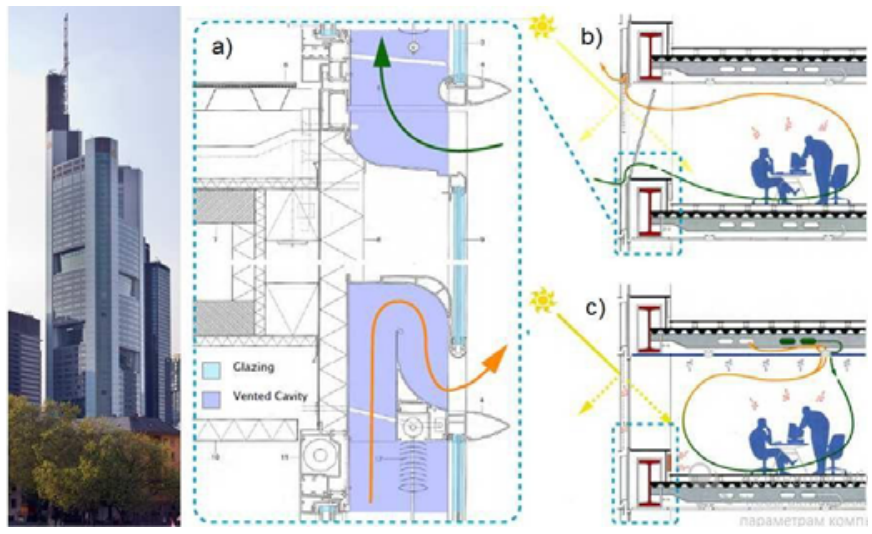

Figure 9. Commerzbank, Frankfurt am Main (German) [21].

a) Double skin façade (vented cavity); b) passive heating/cooling/ventilation system; c) active heating/cooling/ventilation system

"Plan, 'sky' gardens, and a full-height atrium that allows for every office in the tower to have operable windows for views, natural ventilation, and daylight.

The four-storey 'sky' gardens provide fresh air and allow for passive solar gain, while the central atrium space acts like a natural ventilation chimney for the inward-facing offices. Despite the effectiveness of passive systems in Frankfurt's temperate climate zone, Foster recognizes the potential for technical (active) systems to maximize the building's efficiency. A computer controlled building management system decides whether passive or active systems are most appropriate for use at a given time and adjusts openings and shading devices accordingly. During the design of the glazing, 
ventilation slots are included allowing air to enter through the bottom sill of the insulated glass and exit at the head. The fixed exterior glass within the operable window system slows the flow of air avoiding the creation of a draught or the entry of water when the interior portion of the window is opened" [21].

\section{Summary}

Provide the necessary ventilation rate and avoid heat losses due to cooling of you can seal the building as the unit mechanical ventilation with heat recovery exhaust air. Using mechanical air intake and exhaust ventilation system in multi-storey residential buildings requires creating new solutions for air ventilation arrangement. Accordingly the following actions should be taken: to choose an appropriate air intake and recovery scheme, define output of intake and exhaust air fans, determine duct sections values required. But can also be used passive solar heating of the incoming air in the glazed facade. But certainly not always architectural solution allows dominance of glass on the facade. In fact, in this case we are talking about managing heat flows by means of architectural design.

\section{References}

1. Y. Nikitin, V. Goryunov, V. Murgul, N. Vatin, Applied Mechanics and Materials, 680, 504509 (2014)

2. N. Harmati, Z. Jakšić, N. Vatin, (2015) Procedia Engineering, 117 (1), 791-799 (2015)

3. M. Penića, S. Golovina, V. Murgul, Procedia Engineering, 117, 883-890 (2015)

4. Z. Jakšic, D. Ladjinović, M. Trivunić, N. Harmati, N. Vatin, (2015) Procedia Engineering, 117 (1), 507-520 (2015)

5. Feist, W., Schnieders, J., Dorer, V., Haas, A. Re-inventing air heating: Convenient and comfortable within the frame of the Passive House concept (2005) Energy and Buildings, Vol. 37(11), pp. 1186-1203.

6. Gabriyel, I., Ladener, Kh. Rekonstruktsiya zdaniy po standartam energoeffektivnogo doma (St. Peterburg: BKhV-Peterburg, 2011).

7. V. Murgul, D. Vuksanovic, V. Pukhkal, N. Vatin, Applied Mechanics and Materials, 633634, 977-981 (2014)

8. V. Murgul, D. Vuksanovic, N. Vatin, V. Pukhkal, Applied Mechanics and Materials, 635637, 370-376 (2014)

9. V. Murgul, D. Vuksanovic, N. Vatin, V. Pukhkal, Applied Mechanics and Materials, 680, 524-528 (2014)

10. V. Pukhkal, N. Vatin, V. Murgul, Applied Mechanics and Materials, 680, 529-533 (2014)

11. D. Vuksanovic, Y. Nikitin, V. Murgul, N. Vatin, V. Pukhkal, Applied Mechanics and Materials, 680, 499-503 (2014)

12. V. Pukhkal, V. Murgul, M. Garifullin, Procedia Engineering, 117, 624-627 (2015)

13. V. Pukhkal, N. Vatin, V. Murgul, Applied Mechanics and Materials, 633-634, 1077-1081 (2014)

14. V. Murgul, Journal of Applied Engineering Science, 12 (1), 1-10 (2014)

15. R. Alihodzic, V. Murgul, N. Vatin, E. Aronova, V. Nikolić, M. Tanić, D. Stanković, Applied Mechanics and Materials, 624, 604-612 (2014)

16. G. Radovic, V. Murgul, N. Vatin, E. Aronova, Applied Mechanics and Materials, 627, 357364 (2014)

17. V. Murgul, N. Vatin, I. Zayats, Procedia Engineering, 117, 824-829 (2015)

18. G. Radović, V. Murgul, M. Cvetkovska, E. Aronova, N. Vatin, Journal of Applied Engineering Science, 12 (4), 277 - 284 (2014)

19. M. Penić, N. Vatin, V. Murgul, Applied Mechanics and Materials, 680, 534-538 (2014)

20. Y. Tabunschikov, M. Brodach, Energy efficient buildings (Moscow: AVOK-PRESS, 2003)

21. http://www.mbenkert.com/arend.benkert.defilippis.tillmaand.pdf (12.12.2015) 